\title{
Revealing the importance of cooperative ties and R\&D support within Czech manufacturing industry
}

\author{
Viktor Prokop ${ }^{1}$, Jan Stejskal ${ }^{2}$, Ondrej Kuba ${ }^{3}$ \\ University of Pardubice, Faculty of Economics and Administration ${ }^{1}$
}

\begin{abstract}
The importance of cooperation in the field of application knowledge and skills in creative processes is a constantly discussed topic. In general, these processes are described by a many study, but each of them acknowledges the need to take into account the specificities of individual countries and industries. All firms in the knowledge processes use cooperative links with their partners and often also public funds, which the state provides to support increased competitiveness or innovative absorption. Therefore, the aim of this paper has been defined as (i) to verify whether cooperation on innovation activities lead to growth or decrease of firms' turnover and (ii) to find ways to allocate public funds more effectively, because most of innovation activities and cooperation are supported from public funds. Two linear regression models were employed. Data was sourced from a harmonized questionnaire of selected EU Member States from the Community Innovation Survey carried out in the Czech Republic for the period 2010-2012. Analyses have confirmed that collaborative links are at the heart of innovation processes, as well as the manufacturing industry has significant public resources that support these links and influence the growth of their turnover.
\end{abstract}

\section{Introduction}

The fast development of high technology was seen during the last decades in 20th century. In all developed countries the shift towards knowledge and knowledge-based economy in which the creation and use of knowledge have a dominant role in creating prosperity is seen (Prokop and Stejskal, 2018). It led to the emergence of important changes in the production processes all over the world (Chen et al., 2004) and to recognition that knowledge has become one of the most strategic national (corporate) assets, the principal basis for competitive advantage (Marr and Spender, 2004). Ode and Ayavoo (2019) show that knowledge generation, storage and ap-plication have 
significant and positive effect on firm innovation and that knowledge application mediates the relationship between knowledge generation, diffusion, storage and firm innovation. Therefore we can see that countries tend to become not only knowledge but knowledge-based and intensive economies which include structural aspects of technological trajectories and regimes from the systems perspective and contains following areas (Fallah and Ibrahim, 2004): a) knowledge production - which is realized via research and development; b) knowledge transmission - which is achieved via education and vocational training; c) knowledge transfer - in which intentional knowledge exchange occurs between people or organizations; d) knowledge spillover the unintentional transmission of knowledge.

According to abovementioned, there is no doubt that knowledge and innovation are key factors of countries' (firms') competitiveness that significantly influence (sustainable) economic development. These factors push the technological frontier forward and facilitates future innovation, creating spillovers (externalities) and a rational for the use of policy instruments such as the R\&D incentives (Aghion and Jaravel, 2015). Nowadays, we can see that there is a growing consensus that innovation is the key driving force behind economic growth, standards of living, and competitiveness (Hudec, 2015; Visvizi et al., 2018; Stejskal et al., 2018) and therefore the innovation support should be part of the public policy of the country (Ochrana and Nekola, 2009; Nemec, 2015). Some author's (e.g. Amin, 1999; Fothergill and Houston, 2016; Zitek et al., 2016) also state that it is important especially within regions that are seen as important source of competitive advantage within globalized world. Moreover, according to Ferraris and Grieco (2015) regions as innovation catalyst could play the unique role of combining different parties' objectives, facilitating interaction and collaboration among them and protecting, at the same time, the entire innovation environment (ecosystem).

Following previous arguments, it is clear that knowledge and innovation are not created in isolation because firms using inflows and outflows of knowledge can be more successful in accelerating internal innovation and in the expansion of markets for external use of innovation (Bogers et al., 2017) than locked-in firms. It is due to the creation of positive externalities such as knowledge spillover effects. It is important that there are different ways how to create, use and disseminate knowledge and innovation. Cooperation and R\&D with different actors (e.g. suppliers, customers, universities, etc.) as well as creation of network ties between firms and individuals (sharing common goals) seems to be crucial nowadays (Hajkova and Hajek, 2014; Prokop and Stejskal, 2014; Levy and Lubell, 2018). Therefore, this paper focuses on the ways of new knowledge 
resources obtaining and aims (i) to verify whether cooperation on innovation activities lead to the growth or decrease of firms' turnover and (ii) to find ways how to allocate public funds more effectively, because most of innovation cooperation are supported from public funds. The multiple linear regression models were used for the analysis. This analysis is based on data from Eurostat from the Community Innovation Survey between the years 2010 - 2012. The research results will help to define the situation of enterprises in selected branches of manufacturing industry in the Czech Republic and to find the main knowledge resources that affect their innovative activities.

The remainder of this paper has been structured in the following way. The paper first gives a brief overview of the theoretical background. The next section provides details on research methodology and the analysis of research results. Conclusions that have been achieved by the models are described and discussed in the last part, including practical implications and description of future research.

\section{Theoretical framework of the research}

Firms can gain knowledge for their innovation activities from various sources. First, they can use their internal sources and invest to research, buy a technology and learning (creating and disseminating knowledge). Already in the 90s of the 20th century there were some studies (for example Mowery, 2009; Berchicci, 2013) which showed that innovation drivers have changed and that traditional drivers have drastically mutated organizations. It means that the monolithic structure of an internally closed R\&D is rapidly fading and shifting from a vertically integrated in-house $R \& D$ structure to an open $\mathrm{R} \& \mathrm{D}$ structure by tapping into external sources of knowledge through licensing, alliances, technology agreements (Berchicci, 2013) and cooperation via different cooperative ties (e.g. with universities, suppliers, competitors, etc., Prokop et al., 2019). Anzola-Román et al. (2018) also add that nowadays innovations are not just about developing and applying new technologies but also about adopting and reorganizing business routines, internal $\mathrm{R} \& \mathrm{D}$, external relations and marketing. Current studies therefore focus on innovation practices encompassing all those activities aiming to integrate knowledge, resources and expertise from external agents, via cooperation agreements or less formalized procedures, such as the external sourcing of knowledge and ideas.

Therefore, both internal knowledge and external knowledge gained via cooperative ties with different partners or bought on the market (e.g. via contract research) are necessary to hasten the development of firms' innovation activities (Hajek \& Stejskal, 
2018). In this case, the knowledge is seen as a product of cooperation (either between firms or within the firm-university framework or regional triple helix, etc.). The current models of innovation activities in firms are therefore based on an open innovation paradigm where the R\&D structure should be seen as an open system (Chesbrough et al., 2006). These approaches assume that faster and cheaper innovation processes can be achieved by using external knowledge (specifically in combination and from different sources) and stimuli, financial resources, experience, synergies and spillover effects. It is clear because determinants of innovation activities vary across countries (as well as industries) and, separately, influence innovation activities less than in combination with each other (Prokop et al., 2018). It does not mean the deflection from the using of internal ideas and sources. The firm must always be based on their own knowledge (absorptive capacity) and available technologies that form the basis of its innovation portfolio because open innovation and absorptive capacity are two concepts based on the idea that companies can leverage the knowledge generated externally to improve their (internal) innovation performance.

Flor et al. (2018) pointed that internal routines and processes for absorbing external knowledge help to explain radical innovation as they show a significant effect of potential and realized absorptive capacity. They show that there is a moderating effect of absorptive capacity on open innovation and exert a positive effect on the relation-ship between external search breadth and depth and radical innovation. We can generally state that absorptive capacity is seen as the ability of a firm to recognize the value of new (external) information, to assimilate it, and to apply it for commercial needs. Moreover, absorptive capacity plays a leading role in determining the magnitude and range of knowledge flows. Therefore, knowledge absorptive capacity, as a capability that continuously acquires, digests, and utilizes external knowledge, has become an important process necessary for a firm to identify market opportunities and use new knowledge to realize innovation (Xie et al., 2018).

It is clear from abovementioned that absorptive capacity and implementation openness together provide complementary capabilities and generate benefits through economies of specialization from diverse external knowledge sources (Cui et al., 2018). There are also some studies that emphasize that the open innovation approach gives to firms greater benefits than just cost savings and internal research and development (e.g. Cheng and Huizingh, 2014; etc.). It is important especially in a rapidly changing innovation, technology and knowledge environment because mutual knowledge creation and sharing and inter-firm linkages allow firms to achieve greater efficiency and 
performance because of acceleration of new knowledge and technologies as well as because of creation of knowledge spillovers (Stejskal and Hajek, 2015). Companies that have successfully capitalized on integrating external sources of knowledge into their innovation processes primarily stand out in organizational terms and are characterized by growing innovation performance, competitive advantage and organizational flexibility and willingness to restructure their existing business models to accommodate open innovation strategies (Saebi and Foss, 2015).

There is no doubt that inter-firm linkages and technology outsourcing allow firms to keep up with new developments that increase firms' learning gains from cooperation. On the other hand, the higher performance can be affected by several different soft factors such as trust and long-term relationships (based on mutual trust and cooperation), as well as by incorporations into dynamic networks and industrial clusters, appropriately designed regional innovation system and other elements of regional policies that help to create a knowledge-based learning environment (nowadays known as innovation environments/ecosystems). However, the type of collaboration firms engages in (e.g. collaborating locally versus engaging with other actors at a distance) may depend crucially on the institutional conditions, resource endowments as well as on the socioeconomic environment of the region within which the firm is located (Fitjar and Rodríguez-Pose, 2015). Moreover, some scholars (e.g. Chen, 2008; Gnyawali et al., 2016) state that many inter-firm relationships such as strategic alliances and buyersupplier transactions involve the simultaneous pursuit of competition and cooperation (often referred as coopetition). This kind of cooperation involve entities with different identities, motives, and goals that engage in projects aimed at simultaneously creating common value and realizing greater private benefits from that value. It leads to emergence of the paradox (competition-cooperation paradox) of simultaneous competition and cooperation with a close rival.

There are other studies (e.g. Fletcher and Harris, 2012; Laursen et al., 2012) that do not primarily focus on cooperative ties but on different sources of knowledge acquisition. These studies point that acquired knowledge have positive influence on corporate performance (Prochazka and Hajek, 2015). Only some of them deal with the impact of knowledge acquisition sources on the performance. For example, Cruz-González et al. (2014) analyse its impact on the firms' performance in high-technology industries; Rašula et al. (2012) analyse the influence of knowledge acquisition on organizational innovations; Garcia Martinez et al. (2014) focus on the impact of the open innovation strategy on firms' performance. Arvanitis et al. (2015) empirically investigated the 
impact of two external knowledge acquisition strategies (buy and cooperate strategy) on firms' innovation performance and tested complementarity effects in the simultaneous use of these two strategies, as well as the intensity of their use. They show that while both buy and cooperate strategies have a positive effect on innovation, there is little statistical evidence that using them simultaneously leads to higher innovation performance.

Following previous arguments, it is clear, that firms' cooperation (with different partners and by using various different strategies) directed towards a common goal (especially on innovation) should lead to the growth of their performance (turnover). However, the reality is from time to time different and firms' cooperation leads to decrease of their performance. It is also in accordance with Institutional theories that postulate the thesis that the traditional concept of economics includes: (i) problem areas that have not yet been given enough attention; (ii) primary factors for understanding differing economic growth (Prokop and Stejskal, 2018). There is the lack of studies deeply examining the impacts (positive/negative) of these factors, such as firms' cooperation and R\&D knowledge resources on manufacturing firms' innovation activities, especially within countries belonging to the group of Central and East European EU member countries. Therefore, to fill the gap, we analyse the situation in the Czech Republic where the focus of institutional and neo-institutional economics began to develop in the 1990's.

We hypothesize that:

H1: Firms in manufacturing industries in the Czech Republic that cooperated on innovative activities significantly influenced their growth of turnover.

We also investigate following research questions:

RQ1) What kinds of cooperation ties on innovation activities positively influence firms' growth of turnover in manufacturing industries in the Czech Republic?

Moreover, number of firms received financial aids from national and European public funds (specifically to promote innovation activities). In the last years, number of these financial incentives were used ineffectively and, therefore, most of studies analysed the impacts of R\&D subsidies on firms (e.g. Huergo and Moreno, 2014; Czarnitzki and Lopes-Bento, 2014; Bronzini and Piselli, 2016; Halaskova and Halaskova, 2016). For these reasons, we also define second research question:

$R Q 2)$ How and in what combinations should national and European public funds be provided to become more effective to support the growth of firms' turnover in manufacturing industries in the Czech Republic?

Following abovementioned, we created own research model - see Fig. 1. 


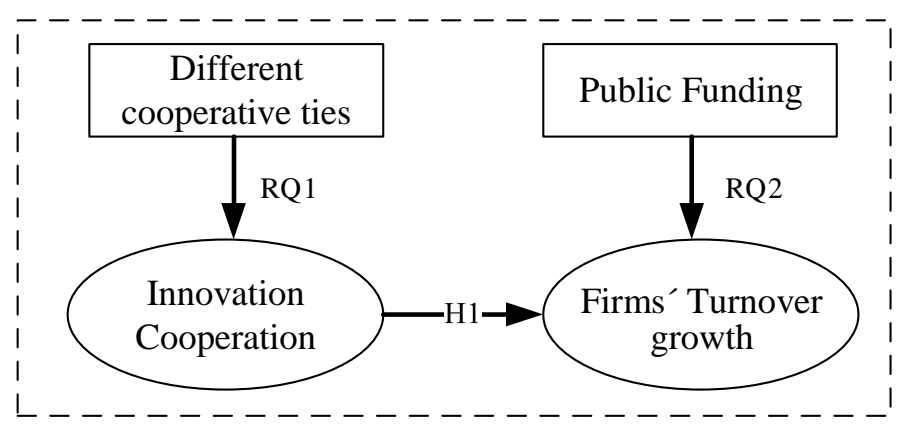

Figure 1 Proposed research model

\section{Data and Research Methodology}

For the data collection, we used a harmonized questionnaire of EU Member States from the Community Innovation Survey (CIS) carried out in the Czech Republic for the period 2010-2012 by combining sample (stratified random sampling) and exhaustive surveys. In total, data on 5,151 Czech firms with at least 10 employees was obtained (response rate greater than $60 \%$ ). For the purpose of this study, we filtered 831 firms from the selected branches of manufacturing industry into data group - specifically, the engineering, electronics and machinery industries - NACE categories $26-30$.

Table 1 Descriptive characteristics for selected branches of manufacturing industry (CZK / in 2012)

\begin{tabular}{lll} 
Innovative & YES & NO \\
\hline Implementation of innovation (product, process) & $55 \%$ & $45 \%$ \\
Total turnover & $1,125,017,400$ & $159,282,565$ \\
Average number of employees & 454.6 & 157.5 \\
Participation in the group of enterprises & $62.8 \%$ & $34.2 \%$ \\
In-house R\&D expenditure & $8,374,310$ & 77,642 \\
External R\&D expenditure & $10,654,056$ & 9,273 \\
Acquisition of equipment & $11,833,807$ & 776,452 \\
Acquisition of external knowledge & $1,693,140$ & 260 \\
Acquisition of other innovation activities & $1,197,391$ & 3,781 \\
Total innovation expenditure & $33,752,704$ & 867,408 \\
Regional and/or national public financial support of innovation & $30.4 \%$ & $1.3 \%$ \\
Public financial support from the EU of innovation & $29.3 \%$ & $1.6 \%$ \\
Cooperation on technical innovation activities & $56.1 \%$ & $3 \%$ \\
\hline
\end{tabular}




\section{Source: own research}

Input and output variables involved in our models are shown in Table 2. As dependent variable, we chose the growth of total turnover between the years $2010-2012$. Growth of turnover is commonly used as dependent variable in similar studies (e.g. Oke et al., 2007; Devons et al., 2016). As independent variables, we used number of categorical and continuous variables that were empirically proved as significant, however in different ways within countries and industries. These variables are: provision of national and/or European public subsidies (Bronzini and Piselli, 2016; Caiazza and Stanton, 2016); cooperation on innovation (Merickova et al., 2016; Prokop et al., 2017); participation in groups of companies (Dachs and Peters, 2014); innovation (specifically product and/or process) activities (McKelvie et al., 2017) and firms (specifically R\&D) expenditures (Gardiner and Hajek, 2016).

\section{Table 2 Input and output variables}

\begin{tabular}{lll} 
Dependent variable & Independent variables (categorical) & $\begin{array}{l}\text { Independent variables } \\
\text { (continuous) }\end{array}$ \\
\hline TURN & FUNNAC & RRDIN/ RTOT \\
& FUNEU & RRDEX/ RTOT \\
CO & ROEK/ RTOT \\
GP & RMAC/RTOT \\
INNI & \\
INNE &
\end{tabular}

\section{Source: own research}

Legend: TURN - the growth of total turnover between the years 2010 - 2012, FUNNAC - regional and/or national public financial support, FUNEU - public financial support from the EU, CO - cooperation on technical innovation activities, GP - part of the group of enterprises, INNI - product/process innovation was developed independently by the firm, INNE - product/process innovation was developed in collaboration with other enterprises, RRDIN - in-house R\&D expenditure, RRDEX external $R \& D$ expenditure, ROEK - acquisition of external knowledge, RMAC acquisition of equipment, RTOT - total innovation expenditure

For analysis of the relationship between variables were used the multiple linear regression models that are commonly used for these kinds of analyses (e.g. Chen and Huang, 2009; Schneider and Spieth, 2013) and therefore we suppose these models sufficient. Our models were fitted to investigate the relationship between one dependent 
variable $y$ represented by the growth of total turnover between the years $2010-2012$ whose value depends on the covariates $\mathrm{x} \cdot \mathrm{j}_{\mathrm{j}}$ (Gustafsson and Wogenius, 2014). Predictors $\mathrm{x}_{1}, \mathrm{x}_{2}, \ldots, \mathrm{x}_{\mathrm{k}}$ (independent variables) of predictant $y$ are listed in the

Table 2. Multiple linear regression models have the following general form (Chatterjee and Hadi, 2013; Vlachogianni et al., 2011).

\section{Results}

Firstly, it was verified that the input data are not correlated with each other by the Spearman test. In addition, collinearity among the independent variables in the regression models was measured using the Variance Inflation Factor (VIF). Multicollinearity was not observed as the values of VIF was in all models <5. To avoid selection bias, in agreement with Frenz and Ietto-Gillies (2009), the treatment effects of innovative/noninnovative firms (with or without product/process innovation) were examined. Treatment-effects estimation was performed using nearest-neighbor matching with Mahalanobis distance. Significant treatment effects were not detected as the p-value was $>0.1$.

We show two similar models (Model 1; Model 2) that confirm the assumption that innovations are not made in isolation. Innovations are created and disseminated effectively through collaboration (in this case: cooperation on technical innovative activities), which ensures the formation of positive spillover effects. Both models were created based on the same data (see Table 2), but cooperation has been involved only in Model 1; Model 2 was created without the involvement of mutual cooperation between firms. The correlation coefficient $\mathrm{R}$ of the first Model 1 reached the value of 0.684 and the coefficient of determination $\mathrm{R}^{2}$ reached 0.468 . P-value of the Model 1 was measured significant at $\mathrm{p}<0.01$. The correlation coefficient $\mathrm{R}$ of the second Model 2 reached the value of 0.384 and the coefficient of determination $R^{2}$ reached 0.148 . P-value of the Model 2 was measured significant at $p<0.01$. The comparison of the models is shown in Table 3 and comparison of research results in Table 4.

Table 3 Comparison of models

\begin{tabular}{lccc} 
& $R$ & $R^{2}$ & $p$ \\
\hline Model 1 & & & \\
Model 2 & 0.684 & 0.468 & $0.0000^{* * *}$ \\
& 0.384 & 0.148 & $0.0002^{* * *}$ \\
\hline
\end{tabular}

Source: own research 
Legend: $\mathrm{R}=$ correlation coefficient; $\mathrm{R} 2=$ coefficient of determination; $\mathrm{p}=\mathrm{p}$-value; $* * *$ significant at $\mathrm{p}<0.01$.

Table 3 shows the importance of cooperation on technical innovative activities. We can see that involvement of cooperation (in the interaction between firms) leads to the strengthening of the Model 1 and to the creation of other significant combinations between variables that significantly influences firms' growth of turnover (see Table 4). These important results let us to confirm our hypothesis that firms (in manufacturing industries in the Czech Republic that cooperated on innovative activities) significantly influence their growth of turnover.

Table 4 Comparison of Model 1 and Model 2

\begin{tabular}{|c|c|c|c|c|}
\hline \multirow{2}{*}{ Variables } & \multicolumn{2}{|c|}{ Model 1} & \multicolumn{2}{|c|}{ Model 2} \\
\hline & P-Value & Beta & P-Value & Beta \\
\hline $\mathrm{CO}$ & $0.0001 * * *$ & 0.2534 & - & - \\
\hline RRDIN/RTOT & $0.0043^{* * *}$ & -0.2597 & $0.0008 * * *$ & -0.3612 \\
\hline RRDEX/RTOT & 0.1748 & -0.0719 & $0.0118 * *$ & -0.1612 \\
\hline RMAC/RTOT & $0.0042 * * *$ & -0.2604 & $0.0004 * * *$ & -0.3793 \\
\hline ROEK/RTOT & 0.1975 & -0.0688 & $0.0333 * *$ & -0.1345 \\
\hline INNI & $0.0001 * * *$ & 0.2534 & 0.1753 & 0.0988 \\
\hline INNE & $0.0006^{* * *}$ & -0.2459 & 0.1637 & -0.1125 \\
\hline FUNEU & $0.0001 * * *$ & -0.2620 & 0.0955 & -0.1260 \\
\hline FUNNAC & $0.0000^{* * *}$ & 0.2747 & 0.1342 & 0.1132 \\
\hline GP & $0.0002 * * *$ & 0.2628 & 0.7314 & -0.0207 \\
\hline INNI*INNE & $0.0000^{* * *}$ & -0.3052 & 0.0764 & -0.1387 \\
\hline INNI*FUNEU & $0.0013^{* * *}$ & -0.2267 & 0.3160 & -0.0787 \\
\hline INNE*FUNEU & $0.0000 * * *$ & 0.2856 & $0.0640 *$ & 0.1457 \\
\hline INNI*FUNNAC & $0.0001 * * *$ & 0.2746 & $0.0485^{* *}$ & 0.1561 \\
\hline INNE*FUNNAC & $0.0000 * * *$ & -0.3088 & $0.0642 *$ & -0.1453 \\
\hline FUNEU*FUNNAC & $0.0015^{* * *}$ & -0.2080 & 0.3355 & -0.0704 \\
\hline INNI*INNE*FUNEU & $0.0003 * * *$ & 0.2536 & 0.1011 & 0.1293 \\
\hline INNI*INNE*FUNNAC & $0.0005^{* * *}$ & -0.2429 & 0.1071 & -0.1256 \\
\hline INNI*FUNEU*FUNNAC & $0.0003^{* * *}$ & -0.2507 & 0.2326 & -0.0945 \\
\hline INNE*FUNEU*FUNNAC & $0.0006 * * *$ & 0.2421 & 0.1867 & 0.1037 \\
\hline INNI*INNE*FUNEU*FUNNAC & $0.0002 * * *$ & 0.2547 & 0.1745 & 0.1055 \\
\hline
\end{tabular}




\begin{tabular}{lllll} 
INNI*CO & $0.0000^{* * *}$ & 0.2954 & - & - \\
INNE*CO & $0.0003 * * *$ & -0.2469 & - & - \\
FUNEU*CO & $0.0002 * * *$ & -0.2628 & - & - \\
FUNNAC*CO & $0.0000^{* * *}$ & 0.2840 & - & - \\
INNI*INNE*CO & $0.0000^{* * *}$ & -0.2829 & - & - \\
INNI*FUNEU*CO & $0.0003 * * *$ & -0.2517 & - & - \\
INNE*FUNEU*CO & $0.0006 * * *$ & 0.2403 & - & - \\
INNI*FUNNAC*CO & $0.0012^{* * *}$ & 0.2223 & - & - \\
INNE*FUNNAC*CO & $0.0000^{* * *}$ & -0.2902 & - & - \\
FUNEU*FUNNAC*CO & $0.0004 * * *$ & -0.2490 & - & - \\
\hline INNI*INNE*FUNEU*CO & $0.0021^{* * *}$ & 0.2175 & - & - \\
INNI*INNE*FUNNAC*CO & $0.0013^{* * *}$ & -0.2267 & - & - \\
INNI*FUNEU*FUNNAC*CO & $0.0003 * * *$ & -0.2603 & - & - \\
INNE*FUNEU*FUNNAC*CO & $0.0003 * * *$ & 0.2534 & - & - \\
INNI*INNE*CO*FUNNAC*FUNEU0.0001*** & 0.2765 & - & - \\
& & & & \\
\hline
\end{tabular}

Source: own research

Legend: $\mathrm{p}=\mathrm{p}$-value; $* * *$ significant at $\mathrm{p}<0.01$; ** significant at $\mathrm{p}<0.05 ; *$ significant at $\mathrm{p}<0.10$; Beta shows whether selected variables influenced dependent variable in positive or negative way and led to its growth or decrease.

Results in Table 4 (Model 1) show how firms' processes are complex and how firms' turnover could be influenced in different ways (to grow/decrease). Firstly, we show which variables (independently) influence the firms' turnover growth or decline. There are variables that significantly led to the firms' turnover growth: cooperation on technical innovation activities, development of product/process innovation independently, regional and/or national public financial support and participation in the groups of firms. On the other hand, the variables - product/process innovation in collaboration with other enterprises, European funding, in-house R\&D expenditures and acquisition of equipment - led in this data set to decrease of the turnover.

Model 1 also shows further significant results of our analysis. We examined the significance of other interactions between different variables that allow creating of the knowledge spillover effects - specifically with focus on product/process innovation, provision of public subsidies and cooperation. These results are the evidence and the source for answering of the question in this research. 
First research question was aimed to determine which form of cooperation influences positively the turnover growth. These ties are for example:

- development of product/process innovation independently in combination with cooperation on technical innovation activities;

- provision of public subsidies from national (or/and regional) funds in combination with cooperation on technical innovation activities;

- development of product/process innovation independently in combination with cooperation on technical innovation activities financed from national (or/and regional) funds and

- development of product/process innovation in collaboration with other enterprises in combination with cooperation on technical innovation activities financed from European funds.

These results provide the important finding: the proper choice of cooperation partners allows the creation of knowledge spillover effects. We showed that there are some variables which affect the turnover negatively in isolation. If these variables are connected with other determinants, their potential is increased, and they can affect the turnover positively (for example: development of product/process innovation in collaboration with other enterprises).

Following results of first research question, we answer the second research area. We analysed the combinations of the national and European public funds (a) to become more efficient allocations and (b) to support the growth of firms' turnover in manufacturing industries in the Czech Republic. The results in Table 4 (Model 1) show that provision of public subsidies from national (and/or regional) funds leads to the turnover growth independently and also to many other combinations. For example, public finance from national (and/or) regional funds significantly influenced firms' growth of turnover in manufacturing industries in the Czech Republic while they were provided to support:

- firms' independent development of product/process innovation;

- firms' independent development of product/process innovation in combination with cooperation on technical innovation activities;

- firms' development of product/process innovation in collaboration with other enterprises in combination with cooperation on technical innovation activities financed from European funds.

On the other hand, European subsidies provision without interactions with other variables led to turnover decrease. On the other hand, we show significant combinations 
of variables (determinants) that caused growth of firms' turnover (after provision of European financial support). These combinations, for example, are:

- development of product/process innovation independently in combination with development of product/process innovation in collaboration with other enterprises;

- development of product/process innovation in collaboration with other enterprises in combination with cooperation on technical innovation activities.

\section{Conclusions}

The success of a firm and its products in a globalized market is conditioned by the possession of production factors, ideally unique production factors, which make it possible to reduce production costs or come to the market with branded new products. Knowledge, creativity and the ability to innovate belong among these crucial production factors. Therefore, it is the application of knowledge in the production process, the use of their synergistic and other spillover effects resulting from the cooperation of economic entities, the emergence of science and research knowledge and their commercialization.

In view of the above mentioned, the aim of this paper was defined as to verify whether cooperation on innovation activities lead to growth or decrease of firms' turnover and to find ways to allocate public funds more effectively, because most of the cooperation is supported from public funds. The subject of the research was companies in the Czech manufacturing industry.

The fundamental finding and conclusion of the study is that cooperation on technical (technological) innovation significantly affects the turnover of the firms. Therefore, it is necessary to recommend that manufacturing firms in the Czech Republic must cooperate in technical innovation processes (the selecting a quality cooperation partner must be the emphasized). These activities should be supported from public finances, especially through the targeting of grant calls. It is necessary to recommend that public bodies focus on creating clear challenges (calls), conditions and, above all, measurable goals that will be incorporated into public policies for the area.

We recognize the weaknesses of this research. One of them is the significance of data and conclusions; these can be applied to a selected group of manufacturing industry firms from the Czech Republic. It is not easy to generalize the results to the whole Czech Republic. Remedying these shortcomings may be the subject of further research. 


\section{Funding}

This paper was supported by the Student Grant Competition (grant no. 18) of University of Pardubice in 2019.

\section{References}

Aghion, P., \& Jaravel, X. (2015). Knowledge spillovers, innovation and growth. The Economic Journal, 125(583), 533-573.

Amin, A. (1999). An institutionalist perspective on regional economic development. International Journal of Urban and Regional Research, 23 (2), 365-378.

Anzola-Román, P., Bayona-Sáez, C., \& García-Marco, T. (2018). Organizational innovation, internal R\&D and externally sourced innovation practices: Effects on technological innovation outcomes. Journal of Business Research, 91, 233-247.

Arvanitis, S., Lokshin, B., Mohnen, P., \& Wörter, M. (2015). Impact of external knowledge acquisition strategies on innovation: A comparative study based on Dutch and Swiss panel data. Review of Industrial Organization, 46(4), 359-382.

Berchicci, L. (2013). Towards an open R\&D system: internal R\&D investment, external knowledge acquisition and innovative performance. Research Policy, 42 (1), 117 127.

Bogers, M., Zobel, A. K., Afuah, A., Almirall, E., Brunswicker, S., Dahlander, L., ... \& Hagedoorn, J. (2017). The open innovation research landscape: Established perspectives and emerging themes across different levels of analysis. Industry and Innovation, 24(1), 8-40.

Bronzini, R., Piselli, P. (2016). The impact of R\&D subsidies on firm innovation. Research Policy, 45(2), 442-457.

Caiazza, R., Stanton, J. (2016). The effect of strategic partnership on innovation: An empirical analysis. Trends in Food Science \& Technology, 54, 208-212.

Chatterjee, S., Hadi, A. S. (2013). Regression analysis by example. New Jersey: John Wiley \& Sons.

Chen, C. J., Huang, J. W. (2009). Strategic human resource practices and innovation performance - The mediating role of knowledge management capacity. Journal of Business Research, 62(1), 104-114.

Chen, J., Zhaohui, Z., Hong, Y. X. (2004). Measuring intellectual capital: a new model and empirical study. Journal of Intellectual Capital, 5(1), 195-212.

Chen, M. J. (2008). Reconceptualizing the competition-cooperation relationship: A transparadox perspective. Journal of Management Inquiry, 17(4), 288-304. 
Cheng, C. C., Huizingh, E. K. (2014). When is open innovation beneficial? The role of strategic orientation. Journal of Product Innovation Management, 31(6), 12351253.

Chesbrough, H. W., Vanhaverbeke, W., West, J. (2006). Open Innovation: Researching a New Paradigm. Oxford University Press, Oxford; New York.

Cruz-González, J., López-Sáez, P., Emilio Navas-López, J., Delgado-Verde, M. (2014). Directions of external knowledge search: investigating their different impact on firm performance in high-technology industries. Journal of Knowledge Management, 18 (5), 847-866.

Cui, T., Wu, Y., \& Tong, Y. (2018). Exploring ideation and implementation openness in open innovation projects: IT-enabled absorptive capacity perspective. Information \& Management, 55(5), 576-587.

Czarnitzki, D., Lopes-Bento, C. (2014). Innovation subsidies: Does the funding source matter for innovation intensity and performance? Empirical evidence from Germany. Industry and Innovation, 21(5), 380-409.

Dachs, B., Peters, B. (2014). Innovation, employment growth, and foreign ownership of firms: A European perspective. Research Policy, 43(1), 214-232.

Devons, D., Lodorfos, G., Kostoupoulos, I., Webber, D. (2016). Innovation and Growth in the City Region: Microeconomic Evidence of Asymmetries. International Journal of Innovation Management, 20(02).

Fallah, M. H., \& Ibrahim, S. (2004). Knowledge spillover and innovation in technological clusters. In Proceedings, IAMOT 2004 Conference, Washington, 1-16.

Ferraris, A., \& Grieco, C. (2015). The role of the innovation catalyst in social innovationan Italian case study. Sinergie, 33(97), 127-144.

Fitjar, R. D., \& Rodríguez-Pose, A. (2015). Networking, context and firm-level innovation: Cooperation through the regional filter in Norway. Geoforum, 63, 2535.

Fletcher, M., Harris, S. (2012). Knowledge acquisition for the internationalization of the smaller firm: Content and sources. International Business Review, 21 (4), 631647.

Flor, M. L., Cooper, S. Y., \& Oltra, M. J. (2018). External knowledge search, absorptive capacity and radical innovation in high-technology firms. European Management Journal, 36(2), 183-194. 
Fothergill, S, Houston, D. (2016). Are big cities really the motor of UK regional economic growth? Cambridge Journal of Regions, Economy and Society, 9 (2), 319-334.

Frenz, M, Ietto-Gillies, G. (2009). The impact on innovation performance of different sources of knowledge: Evidence from the UK Community Innovation Survey. Research Policy, 38 (7), 1125-1135.

Garcia Martinez, M., Lazzarotti, V., Manzini, R., Sánchez García, M. (2014). Open innovation strategies in the food and drink industry: determinants and impact on innovation performance. International Journal of Technology Management, 66 (2), 212-242.

Gardiner, R., Hajek, P. (2016). The role of Innovative SMES to the growth of Regional Economy: The Case of Czech Republic. Economic and Social Development: Book of Proceedings, 630.

Gnyawali, D. R., Madhavan, R., He, J., \& Bengtsson, M. (2016). The competitioncooperation paradox in inter-firm relationships: A conceptual framework. Industrial Marketing Management, 53, 7-18.

Gustafsson, A., Wogenius, S. (2014). Modelling Apartment Prices with the Multiple Linear Regression Model. Stockholm: KTH SCI.

Hajek, P., \& Stejskal, J. (2018). R\&D cooperation and knowledge spillover effects for sustainable business innovation in the chemical industry. Sustainability, 10(4), 1064.

Hájková, V., Hájek, P. (2014). Efficiency of knowledge bases in urban population and economic growth - Evidence from European cities. Cities, 40(PA), 11-22.

Halásková, M., Halásková, R. (2016). Assessment of Financial Capabilities of Local Governments in EU Countries for the Development of Local Public Services. Lex Localis- Journal of Local Self - Government, 14(3), 379-397.

Hudec, O. (2015). Visegrad countries and regions: Innovation performance and efficiency. Quality Innovation Prosperity, 19(2), 55-72.

Huergo, E., Moreno, L. (2014). National or international public funding? Subsidies or loans? Evaluating the innovation impact of R\&D support programmes. Munich: MPRA.

Laursen, K., Masciarelli, F., Prencipe, A. (2012). Regions matter: how localized social capital affects innovation and external knowledge acquisition. Organization Science, 23 (1), 177-193. 
Levy, M. A., \& Lubell, M. N. (2018). Innovation, cooperation, and the structure of three regional sustainable agriculture networks in California. Regional environmental change, 18(4), 1235-1246.

Marr, B., Spender, J. C. (2004). Measuring knowledge assets-implications of the knowledge economy for performance measurement. Measuring Business Excellence, 8(1), 18-27.

McKelvie, A., Brattström, A., Wennberg, K. (2017). How young firms achieve growth: reconciling the roles of growth motivation and innovative activities. Small Business Economics, 49(2), 273-293.

Meričková, B., Prokop, V., Stejskal, J. (2016). Consequences of enterprises' cooperation within the in-novation process - case study of the Czech Machinery Industry. E+ M Ekonomie a Management, 19(3), 110-122.

Mowery, D. C. (2009). Plus ca change: Industrial R\&D in the "third industrial revolution". Industrial and Corporate Change, 18(1), 1-50.

Nemec, J. (2015). Public Policy in the Czech Republic. Central European Journal of Public Policy, 9(1), 7-9.

Ochrana, F., Nekola, M. (2009). Economic evaluation of public programs. Ekonomický časopis, 57(5), $458-74$.

Ode, E., \& Ayavoo, R. (2019). The mediating role of knowledge application in the relationship between knowledge management practices and firm innovation.

Journal of Innovation \& Knowledge. In press. DOI: https://doi.org/10.1016/j.jik.2019.08.002

Oke, A., Burke, G., Myers, A. (2007). Innovation types and performance in growing UK SMEs. International Journal of Operations \& Production Management, 27(7), 735-753.

Procházka, O., Hájek, P. (2015). Modelling knowledge management processes using fuzzy cognitive maps. 10th International Conference on Knowledge Management in Organizations, 224, 41-50.

Prokop, V., \& Stejskal, J. (2018). The effects of cooperation and knowledge spillovers in knowledge environment. In Knowledge Spillovers in Regional Innovation Systems (pp. 3-46). Springer, Cham.

Prokop, V., Stejskal, J. \& Hudec, O. (2019). Collaboration for innovation in small CEE countries. E+M Ekonomie a Management, 22(1), 130-144. 
Prokop, V., Stejskal, J. (2014) Impacts of local planning to competitiveness index change - using approximate initial analysis to the Czech regions. WSEAS Transactions on Business and Economics, 12(1).

Prokop, V., Stejskal, J., \& Hajek, P. (2018). The influence of financial sourcing and collaboration on innovative company performance: A comparison of Czech, Slovak, Estonian, Lithuanian, Romanian, Croatian, Slovenian, and Hungarian case studies. In Knowledge Spillovers in Regional Innovation Systems (pp. 219-252). Springer, Cham.

Prokop, V., Stejskal, J., Kuvíková, H. (2017). The Different Drivers of Innovation Activities in European Countries: A Comparative Study of Czech, Slovak, and Hungarian Manufacturing Firms. Ekonomický časopis (Journal of Economics), $1(65), 31-45$.

Rašula, J., Vukšić, V. B., Štemberger, M. I. (2012). The impact of knowledge management on organisational performance. Economic and Business Review, 14(2), 147-168.

Saebi, T., \& Foss, N. J. (2015). Business models for open innovation: Matching heterogeneous open innovation strategies with business model dimensions. European Management Journal, 33(3), 201-213.

Schneider, S., Spieth, P. (2013). Business model innovation: Towards an integrated future research agenda. International Journal of Innovation Management, 17(01), 1-34.

Stejskal, J., Hájek, P. (2015). Modelling knowledge spillover effects using moderated and mediation analysis - The case of Czech high-tech industries. 10th International Conference on Knowledge Management in Organizations, 224, 329-341.

Stejskal, J., Hajek, P., \& Prokop, V. (2018). Collaboration and innovation models in information and communication creative industries-The case of Germany. Journal of information and communication technology - Malaysia, 17(2), 191208.

Visvizi, A., Lytras, M. D., Damiani, E., \& Mathkour, H. (2018). Policy making for smart cities: Innovation and social inclusive economic growth for sustainability. Journal of Science and Technology Policy Management, 9(2), 126-133.

Vlachogianni, A., Kassomenos, P., Karppinen, A., Karakitsios, S., Kukkonen, J. (2011). Evaluation of a multiple regression model for the forecasting of the 
$2^{\text {nd }}$ International Conference on Research in BUSINESS, MANAGEMENT AND FINANCE

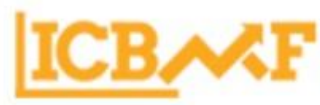

22-24 November, 2019 PARIS, FRANCE

concentrations of NO x and PM 10 in Athens and Helsinki. Science of the Total Environment, 409(8), 1559-1571.

Xie, X., Zou, H., \& Qi, G. (2018). Knowledge absorptive capacity and innovation performance in high-tech companies: A multi-mediating analysis. Journal of Business Research, 88, 289-297.

Zitek, V., Klimova, V., \& Kralova, M. (2016). Assessment of regional innovation systems as an assumption for innovation policy adjustment. Transylvanian Review of Administrative Sciences, 12(49), 169-186. 